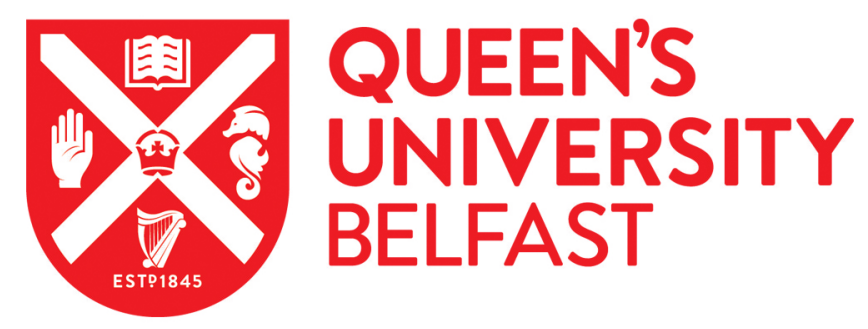

\title{
Violence in the Lives of Children and Youth in "Post-Conflict" Northern Ireland
}

McAlister, S., Haydon, D., \& Scraton, P. (2013). Violence in the Lives of Children and Youth in "Post-Conflict" Northern Ireland. Children, Youth and Environments, 23(1), 1-22. https://doi.org/10.7721/chilyoutenvi.23.1.0001

\author{
Published in: \\ Children, Youth and Environments
}

Document Version:

Publisher's PDF, also known as Version of record

Queen's University Belfast - Research Portal:

Link to publication record in Queen's University Belfast Research Portal

Publisher rights

(C) 2013 Children, Youth and Environments

\section{General rights}

Copyright for the publications made accessible via the Queen's University Belfast Research Portal is retained by the author(s) and / or other copyright owners and it is a condition of accessing these publications that users recognise and abide by the legal requirements associated with these rights.

Take down policy

The Research Portal is Queen's institutional repository that provides access to Queen's research output. Every effort has been made to ensure that content in the Research Portal does not infringe any person's rights, or applicable UK laws. If you discover content in the Research Portal that you believe breaches copyright or violates any law, please contact openaccess@qub.ac.uk. 
Children, Youth and Environments 23(1), 2013

\title{
Violence in the Lives of Children and Youth in "Post-Conflict" Northern I reland
}

\author{
Siobhán McAlister \\ School of Sociology, Social Policy and Social Work \\ Queen's University Belfast \\ Northern Ireland \\ Deena Haydon \\ Childhood, Transition and Social J ustice I nitiative \\ Queen's University Belfast \\ Northern Ireland \\ Phil Scraton \\ School of Law \\ Queen's University Belfast \\ Northern Ireland
}

\begin{abstract}
Citation: McAlister, Siobhán, Deena Haydon, and Phil Scraton (2013). “Violence in the Lives of Children and Youth in 'Post-Conflict' Northern I reland." Children, Youth and Environments 23(1): 1-22. Retrieved [date] from

http://www.jstor.org/action/showPublication?journalCode=chilyoutenvi.
\end{abstract}

\begin{abstract}
While Northern I reland experiences relative peace and political stability, its violent past is normalized in murals and commemorations, the language and posturing of opposition politics, segregated communities and social life. In "post-conflict" Northern I reland, children and youth disproportionately experience paramilitarystyle attacks and routine sectarian violence. The violence of poverty and restricted opportunities within communities debilitated by three decades of conflict is masked by a discourse of social, economic and political progress. Drawing on qualitative research, this paper illustrates the continued legacy and impacts of violence on the lives of children and youth living in post-ceasefire Northern I reland. It discusses the prominence of violence-sectarian, racist, political, "everyday," domestic, "informal"-in young people's accounts and the impacts on their safety, sense of belonging, identity formation, use of space and emotional well-being. The paper concludes by challenging narrow and reductionist explanations of violence, arguing the need to contextualize these within local, historical, political, cultural and material contexts.
\end{abstract}

Keywords: Northern Ireland, violence, conflict, place, identity

(c) 2013 Children, Youth and Environments 


\section{Introduction: The Context and Legacy of Violence}

Potentially the most enduring consequence of the Troubles is the impact on young people throughout 30 years of the Conflict, allied to its perceived legacy on the lives of children and young people growing up in Northern I reland today (Commission for Victims and Survivors Northern Ireland 2010, 125).

Northern Ireland is in transition from over 30 years of sustained political violence. Between 1969 and 1999 it is estimated that 3,636 people died in the Conflict (McKittrick et al. 1999, 147). Given the relatively small population of Northern I reland (around 1.8 million people), the impacts of the Conflict have been pervasive (Fay, Morrision and Smyth 1998). While the number affected by death, injury, trauma and displacement varies according to data source, definition and measurement, recent studies imply that the direct impact is higher than previously estimated. Referring to research undertaken by the Commission for Victims and Survivors in Northern Ireland (CVSNI), McAllister (2011) notes that around 500,000 people consider their lives to have been profoundly damaged by the Conflict. Approximately 170,000 of the current population lost a relative or someone close to them, and 107,000 people in Northern Ireland today consider themselves to have "sustained some kind of injury during... the Troubles" (I bid.).

The consequences of the Conflict were not experienced equally in time, space or social group. In mapping "troubles-related deaths" Fay and colleagues (1998) found that men, younger age groups and those living in areas of economic deprivation were at the highest risk of death. Smyth et al. $(2004,90)$ reported that 40 percent of those killed were aged under 25 . Children are often the forgotten victims, absent from many statistical breakdowns. Yet between 1969 and 1998, 23 children aged five and under, 24 aged between six and 11, and 210 aged 12 to 17 lost their lives as a result of the Conflict (McCrory 2010). Children and youth disproportionately experienced paramilitary punishment attacks, ${ }^{\prime}$ and young men in their twenties were usually the main victims of beatings (Knox 2002, 176).

During the conflict approximately 28,000 people were forced to leave work and 54,000 households compelled to relocate due to intimidation, threats or harassment (Hillyard, Rolston and Tomlinson 2005, 6). Many children within these households, including those experiencing bereavement and/or injury, have become parents of "the ceasefire generation," their trauma unrecognized and untreated (Kilkelly et al. 2004). Since the initiation of the Peace Process there has been an increase in the diagnosis of conflict-related trauma (Gilligan 2006) and increasing suicide rates in communities that suffered the highest levels of economic deprivation and violence throughout the Conflict (DHSSPS 2006, 12-13). It is acknowledged that the Conflict has "generated a legacy of psychological trauma and mental ill-health" which has contributed to "a recognized $25 \%$ higher level of psychological morbidity compared to neighboring jurisdictions" (CVSNI 2010,6). The mental health of contemporary children and youth is of particular concern. 
For over 30 years, violence and insecurity were features of everyday life in Northern I reland. Transition to a "peaceful" society has been slow and not without political or social challenges. In a heavily militarized society, state (formal) and non-state (informal) sanctioned violence affects everyday life, routines and experiences-becoming institutionalized and "normalized." Explaining this "acclimatization" to violence in Northern I reland, Darby and McGinty (2000, 260 in Smyth 2004, 549) state:

Many people... do not live in the war zone, but all are also affected by the custom of violence. This does not mean that large numbers of people become engaged in violent actions. It does not even mean that they acquiesce in those actions. It means that violence and its effects have worked their way into the very fabric of society and become part of normal life so that they become accustomed to the routine use of violence to determine political and social outcomes.

Exemplifying this, despite the claimed cessation of punishment attacks as a consequence of paramilitary ceasefires and agreed dissolution of paramilitary groups, police statistics indicate that of the 272 incidents recorded as "paramilitarystyle attacks" (assaults and shootings) between January 2008 and December 2010, 47 percent were carried out against young people under the age of 25 (Police Service of Northern I reland 2011, 4).

According to CVSNI $(2010,9)$ "the Conflict placed an unequal and devastating burden on young people." This article demonstrates that the legacy of the Conflict and multiple dimensions of deprivation, segregation and sectarianism have particular consequences for the lives of children and youth. It argues that the dual impacts of poverty and the legacy of the Conflict (Horgan and Monteith 2009; McAlister, Scraton and Haydon 2009; Hillyard, Rolston and Tomlinson 2005; Horgan 2005), and the alienation of persistent poverty, have been veiled by the discourse of progress. As Horgan $(2011,456)$ notes, "Although poverty does not cause conflict... conflict feeds on poverty while undermining the potential for those living in poverty to escape it."

\section{Place, I dentity and Violence}

Decades of violence, displacement and population movement have consolidated the historical relationship between place, identity and violence in Northern Ireland. Not only neighborhoods, but entire areas of towns and cities remain synonymous with either the Catholic or Protestant tradition. While Reid $(2004,104)$ notes that constructions of place consist of "a selection of memories and myths" particularly regarding ownership, control and "natural rights," these consolidate over time to create a strong sense of belonging and collective identity tied to place. Mutually exclusive claims to the ownership of space and "the desire to establish a natural and indisputable belonging in place among both communities" underpin "the (sometimes violent) defense of territory" in Northern Ireland (Reid 2004, 103). Communities, policed and defended informally by paramilitaries, established a strong sense of community cohesion derived from experiences of violence and/or discrimination (McAlister, Scraton and Haydon 2009; Knox 2002). 
With cultural identity tied to place, space becomes important at the micro as well as macro level. Thus it is symbolically demarcated (by flags, murals, etc.) and physically defended. In research carried out by the authors, a community representative likened the recent marking of her community with flags to "dogs peeing up against lampposts" (McAlister, Scraton and Haydon 2009, 93). While there is a recognized relationship between place and identity beyond Northern I reland-"questions of 'who we are' are often intimately related to questions of "where we are'" (Dixon and Durrheim 2000, 27) -the defining and labeling influence of place has particular significance in the Northern I reland context.

Exemplifying the enduring relationship between place and identity, and one of the main legacies of the Conflict, is the geographical and educational segregation of the two main ethno-national groups. Approximately 95 percent of social housing in Northern I reland is segregated by religious affiliation (Northern I reland Housing Executive 2006), and over half the population live in almost exclusively Catholic or Protestant neighborhoods (Census 2001) (Census 2011 data not yet available). For many people living in interface areas-geographical points where segregated communities meet-they are often separated from their neighboring community by "peace walls." In 2009 it was estimated that the number of peace walls had trebled in comparison to the number prior to the ceasefires (McDonald 2009). i In addition to residential segregation, 94 percent of the school population attends segregated education in Catholic or Protestant nursery, primary or post-primary schools (DENI 2008, 2). Research consistently reveals that leisure facilities and other services in predominantly Catholic or Protestant communities are not accessed by children and youth outside the community, specifically those from "the other" community (Byrne, Conway and Ostermeyer 2005; Hansson 2005). In addition to structural divisions, the "cultural infrastructure" associated with each community is expressed in preferred sporting activities, newspapers and political parties (Nic Craith 2003 in MacGinty, Muldoon and Ferguson 2007). The role of institutions, particularly the family, community and school, in reproducing ethno-national identities in Northern I reland has been well established (McGrellis 2010; 2005; McAlister, Scraton and Haydon 2009; Leonard 2007; 2004; Smyth et al. 2004; Boal 2002; Connolly and Neill 2001; Gallagher 2001).

The present research explores the advantages and disadvantages of strong communities, traditions and cultures. Benefits include: collective identities, a strong sense of belonging, in-group loyalty and support, community solidarity, good community infrastructure, strong "bonding social capital," psychological security, and positive well-being. Yet they also: restrict opportunities, create difficulties in breaking with community and/or ethno-national traditions, reproduce oppositional and exclusionary identities, maintain sectarianism, and lead to weak "bridging social capital." This article focuses specifically on violence in a divided society, and in the context of marginalization, conflict and transition. It demonstrates the enduring impacts and legacies of the Conflict and how these maintain and facilitate violence between and within communities. We focus first on sectarian violence between communities, how this manifests itself, and its impacts on the lives of children and youth. We then turn to a consideration of violence in the context of 
transition, noting difficulties in breaking with "the past" and dealing with an uncertain future. Finally, we turn to a discussion of the pervasiveness of violence within those communities experiencing the dual impacts of entrenched poverty and the legacies of conflict.

\section{About the Study}

At a time of socio-political transition, our research examined the dual impacts of poverty and the legacy of the Conflict on the lives of children and youth. To interrogate "post-conflict" discourses, the outworkings of the peace dividend and the inclusion of children and youth in the transitional process, we carried out research in six communities-one in each of Northern I reland's six counties. While the research was neighborhood-based, the electoral wards from which the communities were drawn ranged in population size from 1798 to 2790 (NINIS 2010). Out of a total of 582 wards in Northern I reland, all of the communities were located in the top 20 percent most deprived, with four areas featuring in the top 10 percent most deprived wards (Ibid.). They included a mix of urban and rural, Catholic/ Nationalist/ Republican and Protestant/ Unionist/ Loyalist. Within these communities, therefore, the everyday lives of children and youth, their quality of life and opportunities, were shaped by economic deprivation and the legacy of conflict. Profoundly affected by the Conflict, these communities include areas with high numbers of conflict-related deaths (Fay, Morrison and Smyth 1998), sites for the relocation of displaced families who had been intimidated out of their homes elsewhere; areas housing high numbers of families belonging to the security forces; communities that had experienced a heavily militarized state presence; and communities locally known to have been "paramilitary strongholds."

\section{Methods, Sample and Stages}

Data collection involved three stages. The first entailed preliminary explorative focus groups with young people who were working with partner projects. iii This ensured that young people, at least in part, defined the research agenda and the methods by which information was collected. As a consequence, topics were added to the research agenda and methods of data collection adapted to ensure that children and youth of differing abilities could participate in the research.

The second stage of data collection involved semi-structured interviews with adult community representatives $(n=65)$ in the six communities. Their role/work in the communities included: generic and specialist youth and community work, healthrelated provision, child care and family support, formal and informal education, youth training, community restorative justice, community development, criminal justice, community or resident forums. I nterviewing adult representatives provided an insight into the history and background of each community as a way of being able to position the attitudes, behaviors and experiences of children and youth within local, historical, economic, political and social contexts. Key areas of discussion included: history and background of the area (specifically the impacts of poverty and the Conflict); their work (including barriers and enablers); services for children and youth in the community (including gaps in provision); and issues facing children and youth growing up in the community. 
This stage involved numerous visits to communities over several months, providing a grounded understanding of place and identity, familiarizing the researchers with local provision, the layout of the area, internal (often invisible) tensions and divisions, and establishing trust. Community-based representatives supported the research by vouching for its credibility. They encouraged others to participate and introduced the research team to children and youth with whom they worked. This led to the participation of 196 children and youth aged between 8 and 25 years in the research (Table 1).

\section{Table 1. Sample of Children and Youth}

\begin{tabular}{|l|c|c|c|c|}
\hline & $\mathbf{8 - 1 2}$ yrs & $\mathbf{1 3 - 1 7}$ yrs & $\mathbf{1 8 - 2 5}$ yrs & TOTAL \\
\hline Co. Antrim & 21 & 8 & 10 & $\mathbf{3 9}$ \\
\hline Co. Armagh & 3 & 26 & 4 & $\mathbf{3 3}$ \\
\hline Co. Derry & 18 & 29 & 6 & $\mathbf{5 3}$ \\
\hline Co. Down & 33 & - & - & $\mathbf{3 3}$ \\
\hline Co. Fermanagh & - & 18 & 1 & $\mathbf{1 9}$ \\
\hline Co. Tyrone & 1 & 16 & 2 & $\mathbf{1 9}$ \\
\hline TOTAL & $\mathbf{7 6}$ & $\mathbf{9 7}$ & $\mathbf{2 3}$ & $\mathbf{1 9 6}$ \\
\hline
\end{tabular}

Given the limitations of school-based research (Punch 2002; Tisdall et al. 2004), and our commitment to inclusion and participation, children and youth were accessed through youth and community groups. In many respects sampling was opportunistic, involving those available on the days/ evenings we attended. Purposive sampling was also used when there were low numbers of particular age groups. In some communities, however, we found it difficult to access representatives from the youngest (8-12 years) and oldest (18-25 years) age groups.

Methods of data collection included focus groups and in-depth, one-to-one interviews based on interactive, topic-based tasks which stimulated discussion about: how children and youth are viewed, experiences of education and employment, community life, concerns and issues faced by children and youth as they grow up, culture and identity, services and supports, and children's rights. Focus groups enabled participants to define and prioritize issues, challenging the power imbalances inherent in social research (Kitzinger 1995). We also conducted interviews with individual children and youth who had experienced particular "vulnerabilities" (for example, were defined "at risk," had experiences of state care, or had been in conflict with the law).

While stimulus material was designed around all themes (and piloted with a number of groups), it was used with some more than others (mainly younger age groups), and most often in relation to the themes: views of children and youth, community life, and children's rights. Tasks involved children being provided with paper and pens to draw images/write words they felt were associated with children, and those 
they felt were associated with youth. Alternatively, they were encouraged to call out words for the researcher to record on a flip chart. An illustrated "worksheet" on which they were encouraged to note (in whatever format they preferred) the good and not so good things about their communities, was used to introduce the theme of community life. In order to stimulate thinking about "rights," children were presented with an image of a desert island and asked what rights and entitlements they thought everyone on that island should have. This led into a discussion about their knowledge of children's rights and whether they felt their rights were being met. Importantly, these methods were not intended to produce data in their own right but to act as prompts to thinking and sharing ideas on which the researchers would base follow-up questions.

\section{Segregation and Sectarianism: Violence between Communities}

While overall levels of conflict-related violence have decreased, in this research children and youth provided many examples of experiencing or witnessing sectarian confrontations, rioting with the police, and threats/beatings by quasi-paramilitaries. Most, particularly those aged 16 and over, understood how their communities had been affected by, and involved in, violence. They commented that stories passed down in families and communities, or through murals, memorials and commemorations, acted as continuous reminders of the past, and of the impact of the Conflict on "their community":

Like, sectarianism, OK it's bad. But it's like the parents are the worst culprits of it because if young people were allowed to do what they wanted, it wouldn't be as bad as it is. It's the older people that are makin' it so bad, like ... what ye have passed down, like, it just stays with ye sorta thing (Co. Tyrone).

Some felt that these stories, images and events served as reminders of what each "side" had done to "the other" and perpetuated violence:

At the end of the day, we're goin' by what our grannies and granddads are tellin' us. And they're puttin' it on the news and they're makin' films about it. And what are we supposed to think when they make a film about Bloody Sunday or they make a film about the bombings... So of course young ones are goin' to fight back-'Oh, you did this to my ones'-you know, war stories you could say it is (Co. Derry).

Most of the children and youth involved in the research grew up in single-identity communities, were educated in Catholic or Protestant schools and attended youth provision (youth clubs, sporting associations, community-based programs) in their own communities. There were few opportunities, therefore, for cross-community contact. Younger children tended to have limited knowledge and experience of sectarianism, being "cocooned" within their own communities (see Roche 2008) with little opportunity to experience life outside it. With age and experience came an increased understanding of spatial divisions and the relationship between space and ethno-national identity (simply defined by young people as being Catholic or Protestant) - thus the connections between place, identity and safety. An 
understanding of the symbolic and cultural markers of space was necessary for the development of personal/ political identity, the negotiation of everyday life, and ensuring personal safety.

Children and youth understood that where they lived, the school they attended, the uniform they wore, the sporting activities they were involved in, defined them within their cultural tradition. ${ }^{\text {iv }}$ Beyond their neighborhood, there were restrictions on dress, expressing their identity and their movements. They recounted experiences of sectarian harassment, often in "neutral" areas, as pervasive. Schools, families and individuals adopted strategies to promote safety, many of which involved further restrictions on movement and inter-community contact:

Researcher: Would there be, like, clashes then between Catholics and Protestants, would there be fighting or ...?

[Laughter among the group]

YP1: You're in [name of town]!

YP2: It's like, when they get outta the pubs [at separate ends of the town] late at night, they all kinda mix.

YP3: It used to be wile [really/ awful] bad.

YP4: It still is.

YP5: Sure they had to change the time of the schools.

YP6: They had to change the times that the schools were allowed to leave because they were fightin' in the middle of the town. So one school leaves at, like, ten past...

YP7: Like, the Catholic school's right beside the Protestant part, where they all live, and then when the Catholics would be walkin' round the Protestants would be comin' home from school and it would just be causing fights when they met.

YP2: So they get out at different times.

(Co. Tyrone)

Given limited contact, highly segregated lives and notions of "difference" established and reinforced over time, when young people from the two communities met this often resulted in violent clashes. Personal strategies to promote safety included: "managing" or concealing cultural identities when outside their neighborhoods (for example, by altering dress-see McGrellis 2004), avoiding particular places, and staying in groups. Fear of being identified as "the other" impacted not only on feelings of safety and security, but also on choice of facilities or services and young people's freedom of movement. Those who chose to express their identity openly risked sectarian attack. They described how they employed additional methods to negotiate personal safety including being ever vigilant, establishing a reputation for fighting, always being in a group when outside their community, and always being prepared for attack (see also McGrellis 2004; Leonard 2007):

When you're off the estate you're always lookin' where the trouble might come from. Always lookin' over your shoulder... you always have to be in numbers. No way would I walk off the estate on my own (Co. Fermanagh). 
The fear and harassment experienced by some young people were so severe they felt imprisoned within areas that offered few opportunities. They were unable to access nearby youth and leisure facilities as these were in "the other community" or would involve them having to pass through "the other community": "if you walk up yourself then you wouldn't be seen comin' back out" (Co. Fermanagh). Within small towns, areas are clearly demarcated by flags, murals and painted curbstones symbolizing the dominant cultural tradition and "ownership" of space. Places also become labeled over time. A clear understanding and knowledge of place, space and identity is part of the cultural inheritance within and between communities. This knowledge ensures that children and youth understand the "threats" associated with moving beyond boundaries, but it also limits their movement and activities. Consequently, their quality of life is inhibited, restricting their social, cultural, educational and economic opportunities (see Giacaman et al. 2006, 73).

\section{I dentities in Transition: Defending Space and I dentity}

Segregation of the two main communities in Northern I reland maintains and perpetuates difference, ensuring the inter-generational transmission of sectarian ideologies and contested space. Strong, insular communities can lead to a commitment to one's own identity and a subsequent rejection of "the other" (Boal 2002; Forrest and Kearns 2001). Given the relationship between place and identity, this can at times play itself out in the defense or attack of space as a means of asserting one's own identity or repressing that of "the other." Reid $(2004,112)$ notes that within Northern Ireland, "community practices are still predominantly defensive and exclusive."

Illustrating the relationship between place, identity and violence, some young men from both Catholic/ Nationalist and Protestant/ Unionist communities spoke of defending their neighborhoods against "others" entering or moving in. While prepared to accept some level of inter-community contact through sports, youth activities or individual friendships, entering "the others'" community was still risky. Those in a Catholic/ Nationalist community explained:

YP1: I know boys that know Protestants loads, but if they were seen near the Protestant side they'd get hit.

Researcher: "And what about the other way round?

YP2: Aye, if ye seen one [a Protestant] walkin' about here you'd take a swipe at him. (Co. Derry)

Defense of space is tied intricately to defense of identity/culture. In marking (owning) and defending (controlling) space, cultural identity remains "pure" and "uncontaminated" (see McGrellis 2005). In Northern I reland, defense of culture and identity connected to the defense of local space now extends to other "cultures" (Harland 2011; McAlister, Scraton and Haydon 2009). Moves since the ceasefires and Peace Agreements towards "shared space" through its depoliticization (for example, the removal of sectarian/military murals), has led to frustrations among some young people who perceived such approaches as limitations on the expression 
of their cultural identity, while feeling that the same restrictions were not experienced by other cultural groups:

You're not allowed to express your culture. Well, see those bag heads, you know those black people, they're allowed to have those things [turbans] (Co. Fermanagh).

This created resentment and hostility, voiced as dislike of "outsiders" with different identities moving into "their communities." Encouraged by influential adults, occasionally this resulted in violent racist attacks. Analysis of children and youths' accounts revealed racism as an extension of sectarianism-the expectation that defense of one's own identity and place necessitated rejection and exclusion of "others": "We should build a Lithuanian town so they stop comin' here, a separate town" (Co. Armagh). These views were influenced and shaped by older relatives and neighbors.

Young people living in neighborhoods with strong conflict-related political identities were clear that these identities were still very much part of their communities. Yet there was an expectation that they had "moved on," no longer engaging in violence to assert or maintain identity. Sectarianism, violence and rioting were previously associated with a political/ cultural desire for equality, rights and freedoms. Postconflict, such behavior is regularly explained in popular and political discourses as "recreational" (Haydon, McAlister and Scraton 2012; Smyth 2011; Leonard 2010).

In the transition from conflict, reports have emerged of increased insecurity and unease in those communities most affected by political violence-traditionally viewed as strong, stable and secure communities (CTSJI 2010; McAlister, Scraton and Haydon 2009). Those working closely with young people note a lack of purpose, identity and belonging, which manifests itself in violence towards others or the self (Harland 2011; McAlister, Scraton and Haydon 2011; 2009; CTSJI 2010; Harland, Beattie and McCready 2005). At a time of political transition and economic restraint, when the identity and position of working-class young men is uncertain, violence as part of personal, cultural and political identity has persisted. The impact of local changes (for example, the declining influence of paramilitaries, a powersharing government, and the depoliticization of space), alongside global trends (for example, mass youth employment and a more mobile migrant workforce leading to "other cultures" living in traditionally single-identity communities) are significant. There is a sense of loss of, and subsequent search for, identity among some young men, who feel socially and economically marginalized.

Sectarian violence and rioting, rather than being interpreted as "recreational," therefore, requires analysis grounded in an understanding of the cultural identities of the past and the uncertainty of a future determined by political compromise and economic disadvantage. For some young men, sectarianism and rioting had firm personal and political meaning, symbolizing resistance to perceived threats to their ethno-national and masculine identities. Explaining their continued involvement in rioting, young men firmly positioned this action in struggle over ownership of space and the need to ensure that their identities were not "diluted" or "weakened" at a 
time of profound change: "we have to fight for our culture" (Co. Fermanagh, aged 16-25, Protestant/ Unionist community); “We're fightin' for our identity" (Co. Derry, aged 15-19, Catholic/ Nationalist community). The persistence of (and in some cases increases in) violence among young people in "post-conflict" Northern I reland-sectarian violence, rioting, racist hate crimes, youth suicide-does not appear dissimilar to that reported in reunified Germany post-1990s (Kersten 2007). Our findings are consistent with Kersten's research on the "absence of formal and informal social control mechanisms, agencies and routines" during periods of transition. Addressing a "crisis in postwar identity" in Germany, Kersten noted the popular classification of "others" as "the objects of hate and dehumanization" (Ibid., 217).

Global and local changes, rather than creating a sense of opportunity for all, can create uncertainty and dislocation for some, as "increased mobility (forced or voluntary) and the standardizing impulse of global capitalism, may combine to create a sense of dislocation, loss and anxiety, rather than of freedom, progress and choice" (Reid 2004, 108). Threats to group/ national identities can have particularly negative consequences for those who have been most exposed to political violence. Muldoon and colleagues (Muldoon, Schmid and Downes 2009; Muldoon and Downes 2007) found that strong group/ national identities have a protective function, ameliorating the psychological impacts of political violence. In their research with young people, "adolescents with the most experience of violence reported higher levels of psychological well-being where ideological commitment to their group was strong" (Muldoon and Wilson 2001 cited in Muldoon, Schmid and Downes 2009, 131). A clear tension in the transition towards peace, a shared space and future, is that strong social and cultural identities tend to be positive for psychological well-being, yet these are often oppositional/ exclusionary identities which maintain conflict and identity-related violence.

\section{Communities in Transition: Violence and Everyday Life}

The violence that children and youth experience and witness occurs also within families and/or communities. Far from being places of peace and stability, those involved in this research described their communities as places of uncertainty and unease, in which sporadic outbursts of violence were constant. In addition to the continued threat of paramilitary-related violence, there was a perception that "everyday violence" was increasing. This was explained by community representatives as a consequence of declining informal paramilitary policing and a vacuum in formal policing:

The police are not there and the paramilitaries will do nothin' about it.

If something happens now, you feel you have nowhere to go.

From when the paramilitaries moved on it is like a free-for-all here... the days of running to someone and getting it sorted are gone.

In discussing what they disliked most about their communities and would most like to change, many children and youth cited "fighting" or "violence." Their accounts of 
community life revealed that many experience and/or witness high levels of community violence-with consistent reference to "lots of fights," "a wile [awful] lot of riots." In addition to accounts of extreme but less frequent incidents of violence, low-level persistent violence was pervasive. For many, violence was viewed as part of community life. In all areas, children and youth spoke about the inevitability of fighting or violence on the weekends, often relating this to alcohol consumption:

Most time they [people in the area] fight and then you're scared you're gonna get hit when they're fighting (Co. Antrim).

Say people's drinkin' around ye, you'd be afraid somebody's gonna turn on ye and you'd get a wile [awful] beatin' (Co. Derry).

Despite being "normalized," the impacts of potential or actual violence were obvious. Children spoke of being "scared at night," feeling unsafe at particular times or in particular parts of their community.

Many negotiated their lives around the reality and context of violence within their communities. Younger children played close to their home or in their street, avoiding parks when they knew older youth who might intimidate or threaten them may be there. Older youth, often victims of direct or indirect violence as a byproduct of spending time in public spaces, negotiated personal safety by remaining vigilant and staying in groups (see also Harland 2011).

Adult community representatives also spoke of high levels of "aggressive parenting." This was explained as a manifestation of poverty and the out-workings of "buried" trauma. It was recognized that in communities "beleaguered by unemployment, poverty, depression, domestic violence" (Community representative), the capacity of parents to cope with everyday life as well as meet their children's physical, emotional, social and educational development was a constant pressure. Some spoke of "the secrecy" that had contextualized family life in Northern Ireland:

There is an undercurrent of acceptance of violence in our communities-this starts in the home and young people feel there is an acceptable level of violence for them when they are young. All this moves on with age (Community representative).

It [domestic violence] still happens, far more than people will say or admit. It's part of the culture, part of a way of life (Community representative).

The history and pervasiveness of violence has compounded the institutionalization of violence:

We have had 25 years of violence and it has been passed down from generation to generation that violence is acceptable. Parents are violent towards children in the home-they get a good thump-and the young people 
learn that violence is the right way to go, it's the answer (Community representative).

There is a violent nature to the culture [in this area]. There is a mindset that violence is alright-shout to be heard, fight to get by. Status is achieved through violence (Community representative).

While explanations of violence should not be over-simplified, nor such sentiments translated into decontextualized and sensationalist notions of an "addiction to violence," Conflict cannot be under-estimated. High levels of mental ill-health, disability and intergenerational unemployment have consistently been reported in those areas most affected by the Conflict (Horgan 2011; Horgan and Monteith 2009). Smyth (1998, 2) notes that, "In Northern I reland, the effects of Troubles-related violence augment the effects of deprivation, creating a 'double penalty'... deprivation... is interlocked with and compounded by the attritional effect of the violence of the Troubles." Those working in communities were acutely aware of this, working not only with families to support them, but also often as advocates for political recognition and structural change (for example, lobbying for investment into the communities).

The relationship between masculinity and violence in the context of Northern I reland as a conflict-affected society has also been well analyzed (see Harland 2011; Harland, Beattie and McCready 2005). Within our research, children and youth commented on a number of occasions that acting violently was what was expected by their peers, friendship groups and within their community. Defending and asserting personal reputation or that of family, friends and the community were part of local culture and learned through experience. Thus, violence in personal and social interactions was considered a legitimate response. As discussed above, violence was also justified when someone from the "other community" entered the area or attacked friends.

While young women were involved occasionally, violence was an activity most often associated with young men, and was clearly linked to masculine identity. Harland $(2011,428)$ notes that " $\mathrm{t}]$ he complexities and reality of prolonged violence and fear of violence in Northern I reland continue to be an integral and complex aspect of male identity formation." This relationship between masculinity and violence, particularly paramilitary and sectarian violence, has been a defining reality for young men in working-class communities in Northern I reland for many years. It has been closely associated with male identity, and used to maintain difference and assert both masculine and national identity. At a time of political and economic change, when the identity and position of working-class young men is threatened, engaging in violence and sectarianism becomes a means through which power and status is asserted. In this context, "violence... [may be] an expression of young men's hopelessness, frustration, isolation, boredom and energy" (YouthAction Northern I reland 2001, 13). 


\section{Informal Violence, Exclusion and Control}

Added to this is the direct and indirect violence inflicted on young people by adult members of the community, the police or quasi-paramilitaries because of youths' perceived "anti-social" behavior. Since the ceasefires and the decline of paramilitary control within communities, there has been an increased social presence of youth "hanging out" on the streets. While youth define this in terms of sociability and a lack of alternatives, adults have tended to view it as threatening and intimidating:

When we're on the corners we're just gettin' together, havin' a laugh. But straight away they [adults] see it as a threat... Anti-social behavior is simply congregatin' in a group. Just bein' together with your pals is targeted as antisocial. You want to tell them [police, older people] that you're bein' social, not anti-social. They wouldn't get it! (Co. Fermanagh)

If you stand around in groups on the street or somethin' they [adults] feel intimidated and they pick on you, even if you're not doin' nothin' (Co. Derry).

Based on negative perceptions and reactions, young people experience marginalization. Feared, shunned, and effectively excluded from community life and decisions, they often feel that they are neither wanted nor belong:

People aren't bothered with us. They just want us out of their area. But it's our area as well. It's not their place, we've been reared [brought up] here too...

(Co. Fermanagh).

Many recounted how they felt unloved and unwanted. In some cases this extended to feeling rejected by adults within their communities:

They just hate us (Co. Fermanagh).

They think we're scumbags (Co. Armagh).

Not loved and not liked (Co. Derry, aged 9-11).

[You feel] as if you don't belong in the world (Co. Antrim).

Violent, intimidatory and exclusionary responses to young people were enacted by quasi-paramilitaries in four of the six communities. The power and influence of paramilitaries have become institutionalized in communities where they retain status. There is acceptance of their ideologies and acknowledgement of their power to control "anti-social" behavior, low-level crime and young people. In communities where there was felt to be a "policing void," there was a hankering for the past when the paramilitaries "policed, for the most part, with compassion" (Community representative).

Prior to the research, two communities had experienced the death of a young person as the result of "paramilitary-style attacks." At the time of the research, warnings were posted throughout one community concerning the behavior of young 
people. Illustrating the impact, a 13-year-old boy noted that "everybody's scared." Others had received personal warnings or knew individuals who had been beaten and exiled from their communities. Some believed they were targets because of concerns about the behavior of young people more generally:

They [adults] blame us for stuff and we get a bad name for it... and there's cops comin' up round here and there's paramilitaries lookin' round all the time and they blame ye (Co. Derry).

An underlying culture of fear and suspicion remained in communities experiencing the early stages of transition. Children and youth regularly noted feeling unsafe, vulnerable and that they were potential targets for punishment.

"Threatened" and "moved on" by neighbors, the police and quasi-paramilitaries, young people felt they had no right to public space. The level of control they experienced was at odds with adult perceptions of a "policing void" and a lack of formal and informal controls. Young people in at least three of the communities reported police contact consistent with harassment-being regularly stopped and searched, verbally abused/ ridiculed, and threatened with official sanctions (for non-criminal behavior):

... you can't really walk anywhere without them [the police] saying something. They're like, 'Move on, move on!' You just can't stand about anywhere in the town without them tellin' ye to move (Co. Derry).

Police hate the sight of you. We're told we'll get an ASBO [Anti-Social Behavior Order] (Co. Armagh).

Explaining the potential impact:

You're gonna be bad if you're expected to be bad... If the police are always fuckin' annoyin' ya, you're gonna be bad and you're gonna hate the law (Co. Fermanagh).

Poor relationships between young people and the police, and between some communities and the police, sometimes exploded in rioting-an historical expression of resistance in Northern I reland (see Haydon, McAlister and Scraton 2012).

While the contexts varied, all groups of children and youth raised concerns about violence and its impact on their lives and/or communities. Accounts of both lowlevel persistent violence and hidden or indirect violence were pervasive. Children and youth considered that the negative reputation imposed on them was unfair and uninformed. The constant pressure of rejection and exclusion, together with direct threats of violence, undermined their self-confidence and simultaneously provoked angry reactions. Some turned in on themselves, indicated by regular comments about young people taking their own lives and using alcohol as a coping 
mechanism. Others responded through outward displays of violence and anti-social behavior, thus fulfilling and perpetuating the negative labels attributed to them.

\section{Conclusion}

Since the ceasefires in Northern Ireland, the initiation of the Peace Process, the early release of politically affiliated prisoners and the withdrawal of the British Army from the streets, there has been a marked decline in the levels of violence associated with over 30 years of conflict. During the last decade the transition to peace has included devolution of powers from the British Parliament to the Northern I reland Assembly. While these advances are substantial, this research shows that, within and between communities, conflict-related violence remains pervasivereflecting and perpetuating the political ideologies of sectarianism and racism. Young people, because of their age and presence in public space, are affected disproportionately by violence-as witnesses, victims, survivors and/or perpetrators. Informal violence, exclusion and control are regular features of their everyday lives.

Violence is a significant and complex issue in this divided society. It is heightened within communities which endure political and economic marginalization. The recent history of violence underpinning the current period of social and political transition in Northern Ireland, coupled with economic uncertainty, has exacerbated personal, cultural and economic insecurity in communities unprepared and under-resourced for change. During this period, constructions and perceptions of personal, cultural and political identity have had a profound impact on young people's experiences and opportunities.

The dual and long-standing impacts of poverty and the legacy of the Conflict have been masked by the discourse of "progress" and political rhetoric proclaiming "children are our future" (see also Horgan 2011). While young people are seen as the future generation, symbolizing hope and progress, they are simultaneously demonized, excluded and silenced in their communities. Simplistic and irresponsible accounts of "recreational rioting," and media portrayals of the "ceasefire generation" as gratuitously violent and bigoted, decontextualize young people's lives from local, social, historical and material reality. Children and youth living in Northern I reland continue to be socialized and educated in a society where symbols of interpersonal, cultural and institutional violence perpetuate physical and cultural divisions. Analysis that ignores this contributes to a process of labeling, leading to differential regulation and control rather than identifying and meeting need via appropriate services and support. Persistent poverty, historical under-investment, lack of opportunities and intergenerational trauma, alongside a culture of fear and insecurity, impact on the lives of children and youth living in communities most affected by the Conflict. These issues, however, receive relatively little attention in popular or political discourses.

While this research demonstrates the pervasiveness of violence within these communities, it is not accepted or inevitable, or so deeply rooted that it cannot be effectively challenged. Indeed, while the hard-line responses of paramilitaries and vigilantes persist within the communities involved in this research, the most 
visionary alternatives to these responses emerged and consolidated within the communities, sometimes involving former paramilitaries. Many of those involved in paid and voluntary work have successfully challenged reductionist explanations of poverty and violence, raising awareness of the need for structural and institutional change to address the impacts of socio-economic inequalities and inter-community conflict. Their work and support is grounded in an ethos of community development which recognizes strengths within communities, respects and involves young people in decision-making processes, and challenges the "normalization" of violence.

Siobhán McAlister is Lecturer in Criminology in the School of Sociology, Social Policy and Social Work at Queen's University Belfast. Prior to this she was a Research Fellow in the Childhood, Transition and Social J ustice Initiative (CTSJI) at Queen's University Belfast and a Researcher in YouthAction Northern I reland, a voluntary organization working with marginalized young people. Siobhán has been involved in a range of projects concentrating on the lives and experiences of young people, including: Childhood in Transition: Experiencing Marginalisation and Conflict in Northern I reland (2009); Still Waiting: The Stories Behind the Statistics of Young Women Growing up in Northern Ireland (2007); and Children's Rights in Northern I reland (2004). She works closely with NGOs in sharing information and informing research practices.

Deena Haydon is a Postgraduate Researcher in the Childhood, Transition and Social J ustice Initiative at Queen's University Belfast. Previously Senior Lecturer in Education and Childhood Studies and Head of Research in the School of Education, Edge Hill University, England, since 2000 she has conducted research with children and youth in collaboration with children's sector NGOs in England and Northern I reland. In 2008, she was author of the Northern I reland NGO Alternative Report submitted to the United Nations Committee on the Rights of the Child. She has published books, articles, research reports, and resources for practitioners and children.

Phil Scraton is Professor of Criminology, Queen's University, Belfast and Director of the Childhood, Transition and Social J ustice Initiative. His books include:

'Childhood' in 'Crisis'?; Hillsborough: The Truth; Power, Conflict and Criminalisation; The Violence of Incarceration. Editor of a special issue of Current Issues in Criminal Justice Special Issue on the Criminalisation and Punishment of Children and Young People and co-author of Childhood in Transition: Experiencing Marginalisation and Conflict in Northern Ireland (Save the Children); and Children's Rights in Northern I reland ( $\mathrm{NICCY}$ ). He is committed to community-based initiatives, is Chair of the Board of Include Youth and was a member of the Hillsborough Independent Panel.

\section{Endnotes}

i. Prior to the ceasefires, Peace Agreements and institutional changes, many communities in Northern I reland did not accept the formal police force (the Royal Ulster Constabulary) as a legitimate authority. Paramilitary groups regularly policed communities through warnings, exiling and physical punishments (including beatings, 
public humiliation and shooting) of those accused of criminal or anti-community behavior (see Knox 2002 for further detail). The figures presented in this paper are based on official police records and are, therefore, likely to under-estimate the nature and extent of these attacks.

ii. A "peace wall" or "peace line" is a barrier (e.g., wall, gate, fence) generally positioned between a Catholic/ Nationalist community and a Protestant/ Unionist community in response to security concerns. A survey and analysis of interface barriers in Belfast revealed 88 barriers and security structures in existence, considerably more than those authorized and listed by the Northern I reland Office (CRC 2008; Jarman 2008).

iii. The research was a partnership project between Queen's University Belfast, Save the Children and The Prince's Trust. The Prince's Trust works with "marginalized" young people throughout Northern Ireland and facilitated our access to young people via projects located in areas of economic deprivation.

iv. Visual cues-school uniform, football shirts, caps, scarves, jewelry, chosen sportsconnect to cultural identity. Gaelic football tops, for example, are associated with the Catholic/ Nationalist community, Rangers soccer jerseys are associated with the Protestant/ Unionist community.

v. Speaking on BBC Question Time in 2009 on the issue of racist attacks in Belfast, Ester Rantzen (journalist and television presenter) spoke of an addiction to hatred and violence in Northern I reland: "It's as if it gives them a sense of identity because they only know who they are if they know who they hate." I mplying the glorification of violence, and thus decontextualizing the violent history of Northern I reland, she asked: "Is violence something which is so fresh in people's memories that they remember it with affection?" (BBC News 2009).

\section{References}

BBC News (2009). "Rantzen - NI 'Addicted to Hatred'." J une 19. Available from: http: //news.bbc.co.uk/1/hi/northern_ireland/8110100.stm

Boal, F. (2002). “Belfast: Walls Within.” Political Geography 21(5): 687-694.

Byrne, J., M. Conway and M. Ostermeyer (2005). Young People's Attitudes and Experiences of Policing, Violence and Community Safety in North Belfast. Belfast: Northern Ireland Policing Board.

Childhood, Transition and Social J ustice I nitiative (CTSJ I) (2010). Living in a Divided Society. Childhood, Transition and Social J ustice I nitiative, Queen's University, 12-13 April.

Community Relations Council (CRC) (2008). Towards Sustainable Security: Interface Barriers and the Legacy of Segregation in Belfast. Belfast: Community Relations Council.

Commission for Victims and Survivors Northern I reland (CVSNI) (2010). Comprehensive Needs Assessment First Interim Report, September 2010. Belfast: CVS. 
Connolly, P. and J . Neill (2001). "Constructions of Locality and Gender on the Educational Aspirations of Working Class Children." I nternational Studies in Sociology of Education 11(2): 107-129.

Department of Education Northern I reland (DENI) (2008). Enrolments at Schools and in Funded Pre-School Education in Northern Ireland 2007-08.

Statistical Press release, DENI, 26 February.

Department of Health, Social Services and Personal Safety (DHSSPS) (2006). Protect Life. A Shared Vision: the Northern I reland Suicide Prevention Strategy and Action Plan 2006-2011. Belfast: DHSSPS.

Dixon, J. and K. Durrheim (2000). “Displacing Place-Identity: A Discursive Approach to Locating Self and Other." British Journal of Social Psychology 39(1): 27-44.

Fay, M., M. Morrissey and M. Smyth (1998). Mapping Troubles-Related Deaths in Northern Ireland 1969-1998, $2^{\text {nd }}$ ed. Derry/Londonderry: INCORE.

Forrest, R. and A. Kearns (2001). "Social Cohesion, Social Capital and the Neighbourhood." Urban Studies 38: 2125-2143.

Gallagher, T. (2001). "Conflict and Young People in Northern I reland: The Role of Schools." In Smyth, M. and K. Thomson, eds. Working with Children and Young People in Violently Divided Societies. Papers from South Africa and Northern I reland. Belfast: Community Conflict Impact on Children, 51-68.

Giacaman, R., A. Mataria, V. Nguyen-Gillham, R.A. Safich, A. Stefanini, and S. Chatterji (2006). "Quality of Life in the Palestinian Context: An Inquiry in WarLike Conditions." Health Policy 81(1): 68-84.

Gilligan, C. (2006). "Traumatised by Peace? A Critique of Five Assumptions in the Theory of Conflict-Related Trauma." Policy and Politics 34(2): 325-345.

Hansson, U. (2005). Troubled Youth? Young People, Violence and Disorder in Northern I reland. Belfast: Institute for Conflict Research.

Harland, K. (2011). "Violent Youth Culture in Northern I reland: Young Men, Violence, and the Challenges of Peacebuilding." Youth and Society 43(2): 414-432.

Harland, K., K. Beattie and S. McCready (2005). Young Men and the Squeeze of Masculinity: The Inaugural Paper for the Centre for Young Men's Studies. Jordanstown: University of Ulster/YouthAction Northern I reland.

Haydon, D., S. McAlister and P. Scraton (2012) "Young People, Conflict and Regulation." Howard Journal of Criminal Justice 51(5): 503-520. 
Hillyard, P., B. Rolston and M. Tomlinson (2005). Poverty and Conflict in Ireland: An International Perspective. Dublin: Institute of Public Administration/ Combat Poverty Agency.

Horgan, G. (2011). "The Making of an Outsider: Growing Up in Poverty in Northern Ireland." Youth and Society 43(2): 453-467.

---12005). The Particular Circumstances of Children in Northern Ireland. Belfast: Children's Law Centre.

Horgan, G. and M. Monteith (2009). What Can We Do to Tackle Child Poverty in Northern I reland? York: J oseph Rowntree Foundation.

Jarman, N. (2008). "Security and Segregation: Interface Barriers in Belfast." Shared Space (6): 21-34.

Kersten, J . (2007). "Youth Groupings, Identity, and the Political Context: On the Significance of Extremist Youth Groupings in Unified Germany." In Hagedorn, John, ed. Gangs in the Global City: Alternatives to Traditional Criminology. Urbana and Chicago: University of Illinois Press, 204-224.

Kilkelly, U., R. Kilpatrick, L. Lundy, L. Moore, P. Scraton, C. Davey, C. Dwyer and S. McAlister (2004). Children's Rights in Northern I reland. Belfast: Northern I reland Commissioner for Children and Young People.

Kitzinger, J . (1995). "Qualitative Research: Introducing Focus Groups.” British Medical J ournal 311: 299-302.

Knox, C. (2002). “'See No Evil, Hear No Evil': Insidious Paramilitary Violence in Northern I reland." British J ournal of Criminology 42: 164-185.

Leonard, M. (2010). “What's Recreational about 'Recreational Rioting'? Children on the Streets in Belfast." Children and Society 24(1): 38-49.

---- (2007). "Trapped in Space? Children's Accounts of Risky Environments." Children and Society 21(6): 431-445.

---- (2004). Children in Interface Areas: Reflections from North Belfast. Belfast: Save the Children.

MacGinty, R., O. Muldoon and N. Ferguson (2007). “No War, No Peace: Northern Ireland after the Agreement." Political Psychology 28(1): 1-11.

McAlister, S., P. Scraton and D. Haydon (2011). "Place, Territoriality and Young People's Identity in the 'New' Northern I reland." In Goldson, Barry, ed. Youth in Crisis? "Gangs," Territoriality and Violence. London: Routledge, 89-109. 
---- (2009) Childhood in Transition: Experiencing Marginalization and Conflict in Northern I reland. Belfast: Queen's University, Save the Children and Prince's Trust.

McAllister, B. (2011). "Civil Rights for Victims: The Issues We Face." Speech given at McCluskey Civil Rights Summer School, Holy Trinity Church Carlingford, September 24, 2010. Available from: http: //www.cvsni.org/index.php?option=come_content\&view=article\&id=172: civilrights-for-victims-the-issues- we-are-facing \&catid $=44$ : latest-cvsni- news $\&$ l temid $=54$

McCrory, M. (2010). "More than 250 Children Killed During Troubles." Irish News, August 16.

McDonald, H. (2009). “Belfast's 'Peace Walls' Treble after Ceasefires." The Guardian, July 28. Available from:

http: // www.guardian.co.uk/uk/2009/jul/28/peace-walls-belfast-ceasefire.

McGrellis, S. (2010). "In Transition: Young People in Northern Ireland Growing Up In, and Out Of, Divided Communities." Ethnic and Racial Studies 33(5): 761-778.

----(2005). "Pure and Bitter Spaces: Gender, Identity and Territory in Northern Irish Youth Transitions." Gender and Environment 17(5): 515-529.

----(2004). Pushing the Boundaries in Northern Ireland: Young People, Violence and Sectarianism. London: London South Bank University.

McKittrick, D., S. Kelters, B. Feeney and C. Thornton (1999). Lost Lives: The Stories of the Men, Women and Children Who Died as a Result of the Northern Ireland Troubles. Edinburgh and London: Mainstream.

Muldoon, O. and C. Downes (2007). "Social Identification and Post-Traumatic Stress Symptoms in Post-Conflict Northern Ireland." British J ournal of Psychiatry 191: 146-149.

Muldoon, O., K. Schmid and C. Downes (2009). "Political Violence and Psychological Well-Being: The Role of Social Identity." Applied Psychology 58(1): 129- 145.

Northern I reland Housing Executive (NI HE) (2006). "Mixed Housing Scheme Is Launched," October 30. Available from: www.nihe.gov.uk/index/about-ushome/media_centre/news-2.htm?newsid=6630.

Northern I reland Neighbourhood I nformation Service (NI NI S) (2010). Area Profile. Available from: http://www.ninis2.nisra.gov.uk/public/Home.htm

Police Service of Northern I reland (PSNI) (2011). Paramilitary Style Incidents. Freedom of Information Request F-2011-00341. 
Punch, S. (2002). "Research with Children: The Same or Different from Research with Adults?" Childhood 19(1): 321-341.

Reid, B. (2004). "Labouring Towards the Space to Belong: Place and Identity in Northern I reland." I rish Geography 37(1): 103-113.

Roche, R. (2008). Sectarianism and Segregation in Urban Northern Ireland: Northern I rish Youth Post-Agreement. A Report on the Facts, Fears and Feelings Project. Belfast: Queen's University.

Smyth, M. (2004). "The Process of Demilitarisation and the Reversibility of the Peace Process in Northern Ireland." Terrorism and Political Violence 16(3): 544566.

----(1998) Half the Battle: Understanding the Impact of the Troubles on Children and Young People. Derry/Londonderry: INCORE.

Smyth, M., M. Fay, E. Emily and J. Hamilton (2004). The Impact of Political Conflict on Children in Northern I reland. Belfast: Institute of Conflict Research.

Smyth, P. (2011). “Why We Shouldn't Call it 'Recreational Rioting'." J une 24. Available from: http://faircop.org/component/k2/item/93-rioting-recreational.

Tisdall, E.K.M., R. Baker, K. Marshall, A. Cleland, A. Plumtree and J. Williams (2004). 'Voice of the Child' Under the Children (Scotland) Act 1995: Volume 2 - Feasibility Study. Available from: www.scotland.gov.uk/cru/kd01/red/voc2-05.asp

YouthAction Northern I reland (YANI) (2001). Everyday Life: Young Men, Violence and Developing Youth Work Practice in Northern I reland. Belfast:

YouthAction. 